\title{
Ocorrência do Vírus Rice stripe necrosis virus em Lavouras de Arroz do Rio Grande do Sul
}

\author{
João L. N. Maciel' ${ }^{1}$, Marcelo G. de Moraes $^{2}$, Marcus A. K. Almança ${ }^{2}$, Aida T. S. Matsumura² \\ \& Johannes H. Falcade ${ }^{2}$ \\ 1Embrapa Trigo, Cx. Postal 451, CEP 99001-970, Passo Fundo, RS, Brasil, e-mail: jmaciel@cnpt.embrapa.br; \\ ${ }^{2}$ Departamento de Fitossanidade, Faculdade de Agronomia,Universidade Federal do Rio Grande do Sul, \\ Cx. Postal 776, CEP 90001-970, Porto Alegre, RS, e- mail: mgm@ufrgs.br
}

(Aceito para publicação em 01/02/2005)

Autor para correspondência: João L. Nunes Maciel

\begin{abstract}
Ocurrence of Rice stripe necrosis virus in rice crops from Rio Grande do Sul, Brazil

A viral disease in rice (Orysa sativa), caused by Rice stripe necrosis virus (RSNV), is reported for the first time in Rio Grande do Sul, Brazil.
\end{abstract}

Na safra agrícola 2001/02, constatou-se sintomas de plântulas mortas, listras cloróticas em folhas e retorcimento de folhas e panículas (Figura 1A) em lavouras de arroz (Oryza sativa L.) irrigado, localizadas próximas ou no município de Dona Francisca, Região da Depressão Central do Rio Grande do Sul. Como hipótese, sugeriu-se como agente causal dos sintomas o Benyvirus denominado Rice stripe necrosis virus (RSNV) transmitido pelo protista Polymyxa graminis Ledingham, causador do "entorchamiento" ou "crinkling". Para confirmar a hipótese, plantas sintomáticas dessa região foram analisadas para detecção do vírus e do vetor.

Amostras dessas plantas com sintoma de virose foram enviadas ao Centro Internacional de Agricultura Tropical (CIAT), na Colômbia, sendo, as raízes submetidas à coloração com fucsina e analisadas em microscópio ótico para visualização das estruturas do vetor, e os extratos foliares analisados em microscópio eletrônico (JEOL 100SX) para visualização das partículas virais. No Brasil, após purificação parcial segundo o protocolo de Fauquet \& Thouvenel, exceto as etapas de ultracentrifugação (C. R. Acad. Sci. Paris 296:575. 1983), o vírus foi inoculado em folhas de Nicotiana benthamiana Domin, espécie indicadora e, como controle foi inoculado tampão fosfato de potássio $(0,01 \mathrm{M}) \mathrm{pH} 7,2$. Também realizou-se Double Antibody Sandwich-Enzyme-Linked Immunosorbent Assay (DASELISA) com anticorpo policlonal reativo contra RSNV (Morales et al., European Journal of Plant Pathology 5:643. 1999). Além disso, 160 plantas da cultivar IRGA 417 foram cultivadas até 42 dias após a emergência, 80 em vasos contendo solo coletado em áreas com plantas sintomáticas e as outras $80 \mathrm{em}$ solo de áreas com plantas sem sintomas.

$\mathrm{Na}$ análise dos extratos foliares observaram-se partículas virais características de RSNV (Kanyuka et al., Molecular Plant Pathology 4:393. 2003) e nas raízes verificaram-se cistosoros de $P$. graminis (Figura 1B). Somente as plantas de $N$. benthamiana inoculadas com RSNV apresentaram necrose (Figura 1C). No DAS-ELISA todas as amostras de plantas com sintomas foram positivas para RSNV. Os sintomas foram observados apenas nas plantas cultivadas em solo de áreas com plantas sintomáticas.

Assim, conclui-se que o agente causal dos sintomas descritos é Rice stripe necrosis virus.

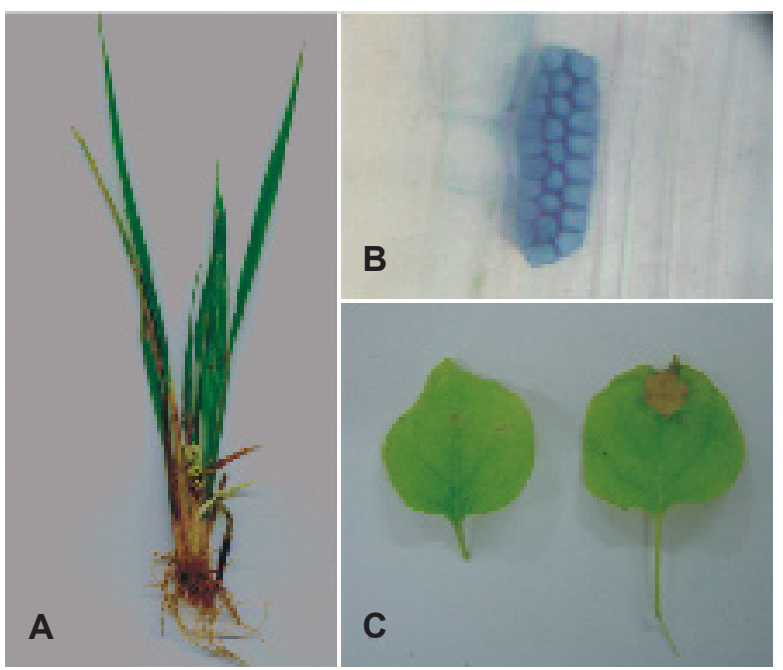

FIG. 1 - A. Planta de arroz (Oryza sativa) com sintoma de Rice stripe necrosis virus (RSNV); B. cistosoro de Polymyxa graminis em aumento de 100x; C. Folhas de Nicotiana benthamiana, a da esquerda inoculada com tampão fosfato de potássio (controle) e da direita inoculada com RSNV, parcialmente purificado. 